\title{
RFLPs Obtained from an rDNA Probe and Detected with Enhanced Chemiluminescence in Apples
}

\author{
Hilde Nybom \\ Balsgård-Department of Horticultural Plant Breeding, Swedish University \\ of Agricultural Sciences, Fjälkestadsvägen 123-1, S-29194 \\ Kristianstad, Sweden
}

\begin{abstract}
Susan Gardiner
Department of Scientific and Industrial Research-Fruit and Trees, Palmerston North, New Zealand

\section{Charles J. Simon \\ U.S. Department of Agriculture, Agricultural Research Service, Washington State University, Pullman, WA 99164}

Additional index words. Malus domestics, paternity analysis, DNA fingerprint, cultivar identification, nonradioactive

\begin{abstract}
Individual-specific DNA fragment patterns were obtained by hybridization of endonuclease-digested apple (Malus $\times$ domestica Borkh.) DNA with a probe (pAR72) derived from the rDNA spacer region of the 'White Angel' crab apple. Fragment detection was carried out with a nonradioactive method, using a horseradish peroxidase-catalyzed luminol oxidation. Paternity could be inferred by comparison of the fragment pattern generated by a seedling with those derived from putative parents.
\end{abstract}

Several recent investigations have reported on DNA fragment patterns obtained from hybridization of apple DNA with various probes. These fragment patterns are generally stable within cultivars (Nybom, 1990a; Nybom et al., 1990) but highly variable among different genotypes (cultivars or seedlings). They have, therefore, proven very useful for cultivar identification (Nybom et al., 1990; Watillon et al., 1991) and pater-

Received for publication 10 July 1991. Accepted for publication 2 Dec. 1991. Financial support to H.N. was given by The Royal Swedish Academy of Forestry and Agriculture. The cost of publishing this paper was defrayed in part by the payment of page charges. Under postal regulations, this paper therefore must be hereby marked advertisement solely to indicate this fact. nity analysis (Nybom, 1990b; Nybom and Schaal, 1990).

However, a serious drawback to the methodology is that fragment detection usually involves the use of radioactive isotopes, e.g. ${ }^{32} \mathrm{P}$. Although several nonradioactive fragment-detection methods have been reported, these have been used almost exclusively in analysis of human DNA (Macedo et al., 1989; Pollard-Knight et al., 1990; Zischler et al., 1989). For plant DNA, fragment detection has been accomplished by using biotin (Hueros et al., 1990), digoxigenin (Weising et al., 1991), and alkaline phosphatase with chemiluminescence (Kreike et al., 1990). However, these studies have not involved a detailed analysis of complex DNA fragment patterns.

In a previous study, DNA extracted from apple seedlings derived by open pollination between cultivars Golden Delicious (GD), Red Delicious (RD), and Jonathan (JO) was digested with the restriction enzyme TaqI, and in some cases also with RsaI, and electrophoresed in an agarose gel (Nybom and Schaal, 1990). The resulting gels were Southern-blotted onto Nytran nylon filters (Schleicher \& Schuell, Dassel, Germany) and hybridized initially to a ${ }^{32} \mathrm{P}$-labelled M13 minisatellite probe. The highly variable DNA fingerprints obtained enabled deductions about paternity in 56 out of 64 cases (Nybom and Schaal, 1990). In the present study, filters with the RsaI-digested samples were hybridized to the pAR72 probe derived from an rDNA spacer region of the 'White Angel' crab apple (Simon and Weeden, 1991). DNA fragments were detected with the enhanced chemiluminescence kit from Amersham International (Amersham, Great Britain), which uses a horseradish peroxidase-catalyzed luminol oxidation (Durrant et al., 1990). Probe labelling, hybridization (in the presence of $0.5 \mathrm{M} \mathrm{NaC1}$ and $5 \%$ blocking agent), and washing were carried out according to the manufacturer's instructions. The detection reaction was performed by placing the nylon filter, dried of surface moisture, on a Whatman no. 3 filter paper soaked with the detection reagents. Both were quickly enclosed in a Photogene development folder (Life Technologies, Gaithersburg, Md.), the edges of which were then sealed with waterproof tape, and the filter was exposed to Fuji Xray film in a photographic cassette. Exposure was from 15 min to $2 \mathrm{~h}$ to detect fragments of differing hybridization intensity.

Altogether, 32 seedlings, divided on to two filters, were analyzed. Each seedling had $» 10$ strongly hybridizing fragments and 10 to 15 weaker ones (Fig. 1). No seedlings were completely identical. Nine fragments, existing in one or two of the parental cultivars but not in all three, were scored on one filter, and eight fragments were scored on the other filter due to somewhat lower probe activity. JO had fragments 2, 3, 6, 8, and 9; GD fragments 4 and 7; RD fragments 1 (could not be scored on one of the filters), 3, 5, and 7. By comparison of the fragment profile of a seedling with those of its putative par- 


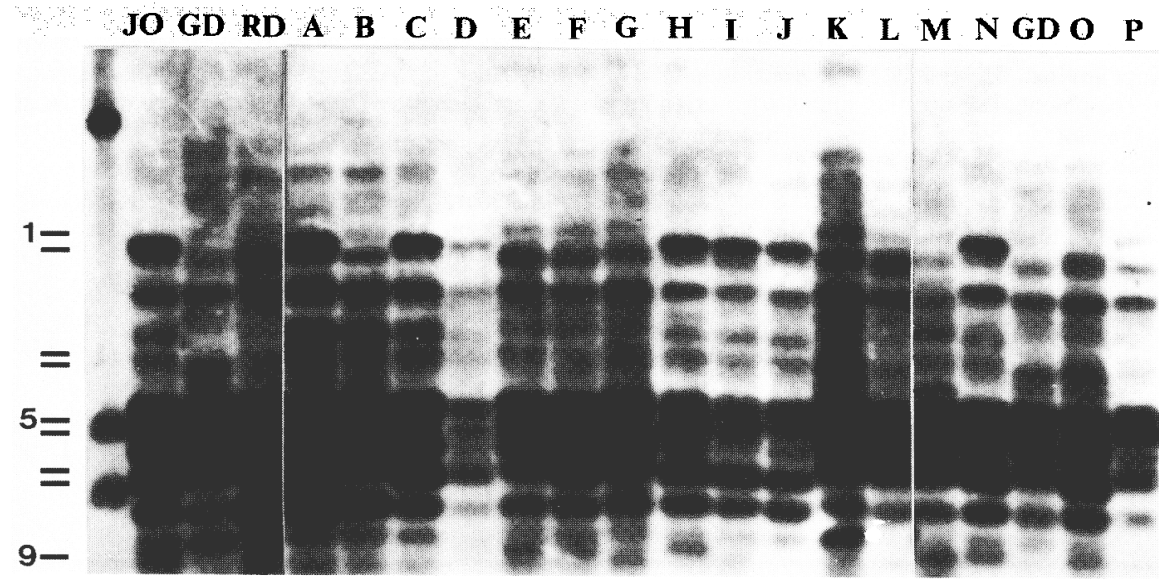

Fig. 1. DNA of apple cultivars (GD = 'Golden Delicious', JO = 'Jonathan', RD = 'Red Delicious') and 16 apple seedlings (A-P) digested with RsaI, hybridized with the pAR72 rDNA probe, and detected by enhanced chemiluminescence. Size markers (lane 1), $4.4 \mathrm{~kb}, 2.3 \mathrm{~kb}$, and $2.0 \mathrm{~kb}$, obtained by digesting $\lambda$ DNA with HindIII. Markers left of photo denote the nine fragments used for the paternity test.

ents, paternity could be deduced for the majority of the seedlings.

Two out of five seedlings previously assigned to a cross of JO $\times$ GD $($ Nybom and Schaal, 1990) were reconfirmed. However, the remaining three lacked diagnostic fragments since all their fragments were also found in JO.

Of nine seedlings previously assigned to $\mathrm{JO} \times \mathrm{RD}$, six were reconfirmed, whereas the remaining three had only JO fragments.

One seedling was assigned to GD $\times$ JO in concordance with the previous study.

Six of nine seedlings, previously assigned to $\mathrm{GD} \times \mathrm{RD}$, were reconfirmed. Two of the remaining seedlings in this group had one fragment found in both JO and RD and, thus, paternity could not be deduced. The third had a fragment not found in any of the three cultivars and was therefore probably derived by pollination from an outside source.

In two seedlings derived from JO, only JO fragments were found in the previous study, suggesting that these seedlings originated through selfing. One of these seedlings again had only JO fragments. However, the other seedling had a. fragment found in GD and RD but not in JO, showing that it was actually derived through cross-pollination.

Two JO seedlings previously exhibited fragments not found in any of the three cul- nucleic acid detection. BioTechniques 8:564570

Hueros, G., J.V. Monte, and E. Ferrer. 1990. Hordeum chilense repetitive sequences. Genome characterization using biotinylated probes. Theor. Applied Genet. 80:24-32.

Kreike, C.M., J.R.A. de Koning, and F.A. Krens. 1990. Non-radioactive detection of single-copy DNA-DNA hybrids. Plant Mol. Biol. Rptr. 8:172-179.

Macedo, A. M., A.C. Medeiros, and S.D.J. Pena. 1989. A general method for efficient non-isotopic labeling of DNA probes with M13 vectors: Application to DNA fingerprinting. Nucleic Acids Res. 17:4414.

Nybom, H. 1990a. DNA fingerprints in sports of 'Red Delicious' apples. HortScience 25:16411642 .

Nybom, H. 1990b. Genetic variation in ornamental apple trees and their seedlings (Malus, Rosaceae) revealed by DNA 'fingerprinting'. Hereditas 113:17-28.

Nybom, H. 1991. Applications of DNA fingerprinting in plant breeding. p. 294-311. In: T. Burke, G. Dolf, A.J. Jeffreys, and R. Wolff (eds.). DNA fingerprinting Approaches and applications. Birkhäuser, Basel, Switzerland.

Nybom, H., S.H. Rogstad, and B.A. Schaal 1990. Genetic variation detected by use of the M13 "DNA fingerprint" probe in Malus, Prunus, and Rubus (Rosaceae). Theor. Applied Genet. 79:153-156

Nybom, H. and B.A. Schaal. 1990. DNA "fingerprints" applied to paternity analysis in apples (Malus $\times$ domestica). Theor. Applied Genet. 79:763-768.

Pollard-Knight, D., A.C. Simmonds, A.P. Schaap, H. Akhavan, and M.A.W. Brady. 1990. Nonradioactive DNA detection on Southern blots by enzymatically triggered chemiluminescence. Anal. Biochem. 185:353-358.

Simon, C.J. and N.F. Weeden. 1991. Molecular analysis and cloning of Malus ribosomal DNA. J. Amer. Soc. Hort. Sci. 117:164-168.

Watillon, B., P. Druart, P. Du Jardin, R. Kettmann, and A. Burny. 1991. Use of random cDNA probes to detect restriction fragment length polymorphisms among apple clones. Scientia Hort. 46:235-243.

Weising, K., B. Beyermann, J. Ramser, and G. Kahl. 1991. Plant DNA fingerprinting with radioactive and digoxigenated oligonucleotide probes complementary to simple repetitive DNA sequences. Electrophoresis 12:159-169.

Zischler, H., I. Nanda, R. Schafer, M. Schmid, and J.T. Epplen. 1989. Digoxigenated oligonucleotide probes specific for simple repeats in DNA fingerprinting and hybridization in situ. Human Genet. 82:227-233. 